\title{
Comparison of biostimulation and bioaugmentation for remediation of soil contaminated with spent motor oil
}

\author{
${ }^{1 *}$ S. Abdulsalam; ${ }^{2}$ I. M. Bugaje; ${ }^{3}$ S. S. Adefila; ${ }^{4}$ S. Ibrahim \\ Chemical Engineering Programme, Abubakar Tafawa Balewa University, Bauchi, Nigeria \\ Department of Chemical Engineering, University of Maiduguri, Borno State, Nigeria \\ Department of Chemical Engineering, Ahmadu Bello University Zaria, Nigeria
}

Department of Biochemistry and Director Centre for Biotechnology, Ahmadu Bello University Zaria, Nigeria

Received 30 July 2010; $\quad$ revised 3 September 2010; accepted 12 November 2010; available online 1 December 2010

\begin{abstract}
Aerobic fixed bed bioreactors were used to study and compare biostimulation and bioaugmentation for remediation of soil contaminated with spent motor oil. Bioaugmentation using consortium of bacteria and biostimulation using inorganic fertilizer and potassium dihydrogen orthophosphate were investigated. The bioremediation indicators used were the oil and grease content removals, total heterotrophic bacteria counts and carbon dioxide respiration rates. Results showed that biodegradations were very effective with 50, 66 and $75 \%$ oil and grease content removal efficiencies for control, bioaugmentation and biostimulation respectively after ten weeks. Carbon dioxide respiration followed similar pattern as the oil and grease content removals. Biostimulation option has the highest carbon dioxide generation (6 $249 \mathrm{mg} / \mathrm{kg}$ ) and the control with the least (4 $276 \mathrm{mg} / \mathrm{kg}$ ). Therefore, the biostimulation option can be used to develop a realistic treatment technology for soils contaminated with spent motor oil.
\end{abstract}

Keywords: Bacterial count; Bioremediation; Carbon dioxide respiration; Closed system; Fixed bed bioreactor; Oil and grease content

\section{INTRODUCTION}

The quality of life on earth is linked, inextricably, to the overall quality of the environment. Releases of persistent, bioaccumulative and toxic chemicals have a detrimental impact on human health and the environment. These contaminants find their way into the tissues of plants, animals and human beings by the movement of hazardous constituents in the environment. Contaminated lands generally result from past industrial activities when awareness of the health and environmental effects connected with the production, use, and disposal of hazardous substances were less recognized than today (Vidali, 2001). The problem is worldwide, but more severe in the developing countries where there were no effective regulatory policies on the environment. It is now widely recognized that contaminated land is a potential threat to human health, and its continual discovery over recent years has lead to international efforts to remedy

*Corresponding Author Email: asurajud@yahoo.com Tel.: +234 80328394; ; Fax: +98 2182883381 many of these sites, either as a response to the risk of adverse health or environmental effects caused by contamination or to enable the site to be redeveloped for use. Petroleum contaminants are typical examples of these hazardous constituents. Soil contaminated with petroleum products can be defined as any earthen material or artificial fill that has human or natural alteration of its physical, chemical, biological or radiological integrity resulting from the introduction of crude oil, any fraction or derivative thereof (such as gasoline, diesel, or motor oil), or oil-based product. (Dhanasekaran et al., 2009; Chukwuma et al., 2010; Refaat, 2010) Because of these alterations and potential threat to public health and the environment, some forms of remediation become imperative. Physicochemical technologies have been used for ages for the treatment or disposal of soils contaminated with petroleum products (Adams et al., 2009; Yousefi Kebria et al., 2009). These technologies include: thermal treatment, dig and dump method, chemical method, 
separation techniques and stabilization/solidification technology. However, the physicochemical technologies have their limitations (Less and Senior, 1995; Vidali, 2001). These limitations include: they are expensive to implement at full scale, they are not environmentally friendly, their technologies are complex and they lead to destruction of soil texture and characteristics. (Zhang et al., 2009) Furthermore, the physicochemical technologies do not always result in complete neutralization of pollutants (Yerushalmi et al., 2003). Due to limitations of the physicochemical technologies stated above, great deals of literature have reported that bioremediation technologies are alternatives and or supplements to these technologies. This is because of their cost effectiveness, environmental friendliness, simplicity in technology and conservation of soil texture and characteristics (Vidali, 2001; Yerushalmi et al., 2003; Adams and Guzman-Osorio, 2008; Fouépé et al., 2009). Oil spills from the refineries, industries, filling stations, loading and pumping stations, petroleum products depots, during transportation and at auto-mechanics workshops all contribute to soil contamination, and actually make up a larger percentage of polluted ground in the world versus those contaminated by catastrophic spills. The dig and dump method of disposing these oil polluted lands is expensive and only transfer the contamination from one place to another. This disposal technique is very prominent in the developing countries, where there were no effective regulatory policies on the environment. In no doubt, the dig and dump practice has led to the contamination of thousands of other sites remote from their place of initial contamination and therefore, urgent actions need to be taken for environmental safety in general and of public health importance. In most developing countries, oil spills at auto-mechanic workshops have been left uncared for over the years and its continuous accumulation is of serious environmental concern because of the hazard associated with it. For instance, spent motor oil disposed off improperly contains potentially toxic substances; such as benzene (carcinogens), lead, arsenic, zinc and cadmium, which can seep into the water table and contaminate ground water (Igwe et al., 2008; Shah et al., 2009). It consequently results in serious health hazard such as anemia and tremors, which can cause death. Bioremediation is the naturally occurring process by which microorganisms transform environmental contaminants into harmless end-products. It is a promising, innovative and cost effective technology for use in the cleanup of hazardous wastes. For bioremediation to be effective, microorganisms must enzymatically attack the pollutants and convert them to harmless products (usually carbon dioxide and water).

Bioremediation can only be effective, if the environmental conditions permit microbial growth and activity; its application often involves the manipulation of environmental parameters to allow microbial growth and degradation to proceed at a faster rate (Vidali, 2001; Nwuche and Ugoji, 2008; Nwuche and Ugoji, 2010). The extent of biodegradation is highly dependent on the toxicity and initial concentrations of the contaminants, their biodegradability, the properties of the contaminated soil, and the particular treatment system selected (Chambers, et al., 1991; Less and Senior, 1995).

There are two approaches to bioremediation, the biostimulation and the bioaugmentation; biostimulation involves identifying and adjusting certain physical and chemical factors (such as soil temperature, $\mathrm{pH}$, moisture content, nutrient content e.t.c) that may be impeding the rate of biodegradation of the contaminants by the indigenous microorganisms in the affected site. Once the factors have been adjusted appropriately, the contaminant biodegradation may proceed at appreciable and satisfactory rates (Chambers, et al., 1991; Kosteck and Calabrese, 1991). On the other hand, the bioaugmentation involves the addition of highly concentrated and specialized populations of specific microbes into a contaminated site to enhance the rate of contaminant biodegradation in the affected soil or water because the density of contaminant-specific degraders will have been artificially increased (Chambers, et al., 1991; Kosteck and Calabrese, 1991; Malakootian et al., 2009). Most work reported in the literature on the biological treatment of soil contaminated with used motor oil had been focused on the identification of microorganisms, which can be used to degrade used motor oil (Amund et al., 1987) and the use of plants for the degradation of used motor oil (Anoliefo and Edegbai, 2000). Besides, other works prior to this investigation were based on biological treatments of soil contaminated with spent motor oil in open microcosms (Bagherzadeh-Namazi et al., 2008; Abdulsalam and Omale, 2009). The objectives of this study were to examine the effectiveness of bioremediation of spent motor oil contaminated soil in a closed system and to compare the hydrocarbon removal efficiencies of spent motor oil contaminated soil between 
the bioaugmentation and biostimulation approaches in order to develop a viable treatment technology. To our knowledge, this is the first experimental study, which investigated biodegradation of soil contaminated with spent motor oil in a closed aerobic fixed bed bioreactor. This study was conducted between September, 2008 and December, 2008 in Abukakar Tafawa Balewa University Bauchi-Nigeria.

\section{MATERIALS AND METHODS}

\section{Materials}

Sample collection

Top soil $(0-16.4 \pm 0.3 \mathrm{~cm})$ contaminated with spent motor oil with contamination history of about 40 years was collected from a typical auto-mechanics workshop (Baban Kaduna Auto-Mechanics Workshop) located at Tudun Wada in Zaria, Kaduna State-Nigeria and was transported at $4{ }^{\circ} \mathrm{C}$ to Bauchi (about five hours journey by road) where the experiments was conducted. The bacteria (Pseudomonas aeruginosa (Kiyohara et al., 1992; Nnamchi et al., 2006) and Bacillus subtilis (Abdulsalam and Omale, 2009) and the Fertilizer (NPK 20:10:10) used were obtained from the National Veterinary Research Institute Vom, Plateau State-Nigeria and Bauchi Fertilizer Company Limited, Bauchi-Nigeria respectively. In addition, potassium dihydrogen orthophosphate $\left(\mathrm{K}_{2} \mathrm{HPO}_{4}\right)$ used was of analytical grade.

\section{Methods}

Process description

Each biodegradation investigation was carried out in an aerobic fixed bed bioreactor labelled TR1 (contro), TR3 (bioaugmentation), and TR6 (biostimulation). An amount of $1.5 \mathrm{~kg}$ of contaminated soil sample was inoculated into each of these bioreactors; this included, where appropriate, the various additives at room temperature of $2133 \mathrm{CFU} / \mathrm{g}$ CS of consortium of Pseudomonas aeruginosa and Bacillus subtilis or $30.42 \mathrm{~g}$ of NPK 20:10:10 and $5.6 \mathrm{~g}$ of $\mathrm{KH}_{2} \mathrm{PO}_{4}$ to give a carbon : nitrogen : phosphorus molar ratio of 100:10:1 or heating at $121^{\circ} \mathrm{C}$. The bioreactors were completely closed in order to avoid $\mathrm{CO}_{2}$ leakage to the

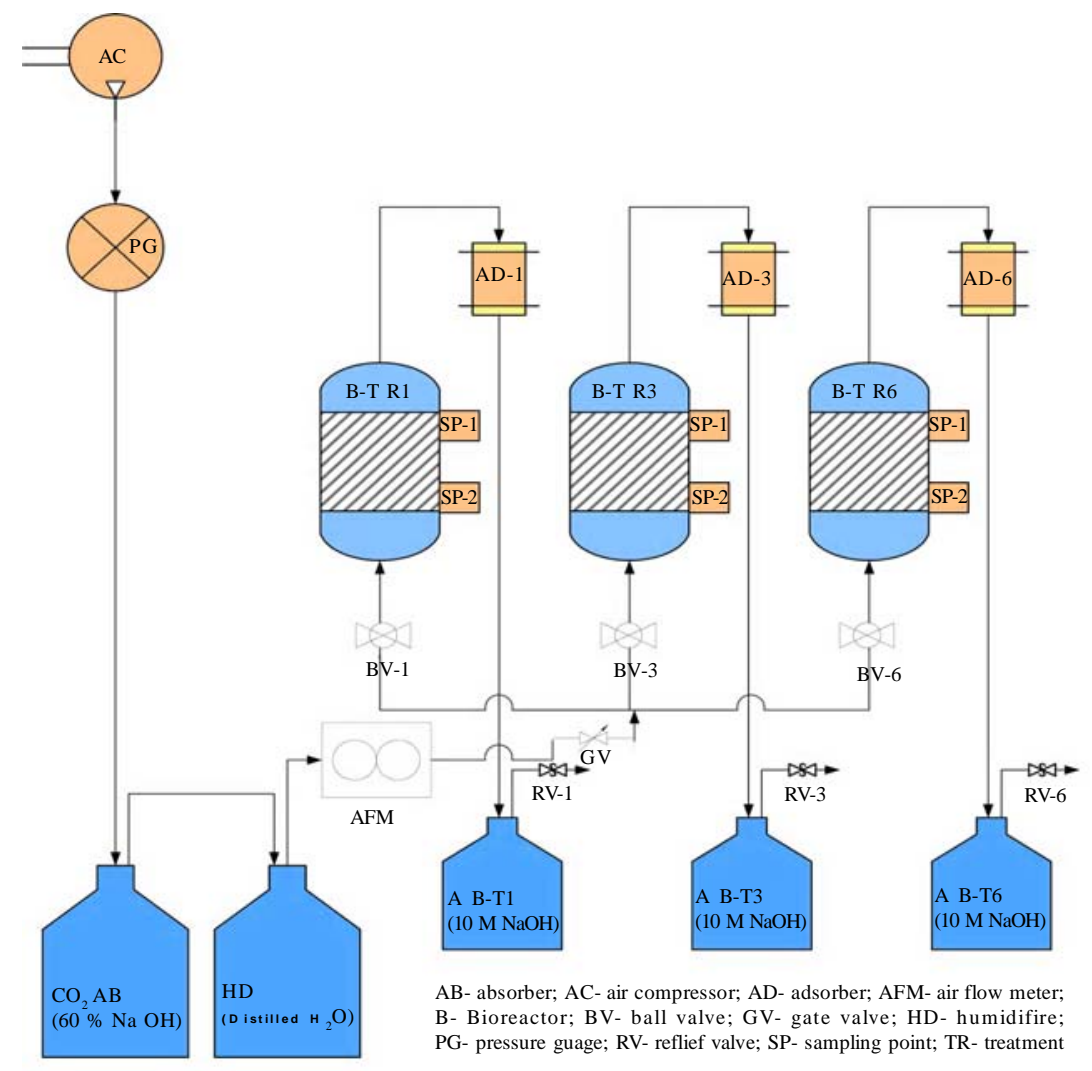

Fig. 1: Experimental Rig for the Rehabilitation of SCSMO in Aerobic Fixed Bed Bioreactors 
environment before passing into $\mathrm{CO}_{2}$ traps. The process flow diagram is presented in Fig. 1. The absorber (AB) before the bioreactors contained a solution of $60 \%$ $(\mathrm{w} / \mathrm{v}) \mathrm{NaOH}$ used to absorb $\mathrm{CO}_{2}$ from the atmosphere and the humidifying unit (HD) to moisten the air before entering the bioreactors. The absorbers, after the bioreactors, contained $10 \mathrm{M}$ solution of $\mathrm{NaOH}$ each meant to absorb the $\mathrm{CO}_{2}$ generated from the bioremediation processes. The moisture content in all the treatments was set at $20 \%(\mathrm{w} / \mathrm{w})$ at the initiation of bioremediation. The airflow rate was maintained in all cases at an average rate of $10 \mathrm{~L} / \mathrm{hr}$ using a flow meter for fourteen hours daily over the period of investigation. The progress of the biodegradation process was assessed by the measurement of the oil and grease content (O\&G), the total heterotrophic bacteria counts (THBC) and physicochemical parameters in the microcosms on a weekly basis. In addition, the $\mathrm{CO}_{2}$ respiration rates for each treatment were measured on 48 hourly basis.

Physicochemical and microbiological characteristics of contaminated soil

Physicochemical and microbiological properties of each treatment were determined by the following standard methods.(ASTM, 1982a and 1982b).

- Particle size distribution was determined based on the Unified Soil Classification (ASTM-D 422-63).

- Bulk and particle densities were determined using the gravimetric analysis and soil porosities calculated from bulk and particle densities values (Brady and Weil, 1999)

- Soil pH was determined using the method of Bates (1954) and moisture contents by the ASTM-D2216

- Available phosphorus in soil samples was determined using the spectrophotometer (Ascobic acid molybdate method) and total nitrogen content by the Kjedahl method

- The temperature was measured using a digital thermometer.

- Indigenous bacteria identification was carried out by morphological and biochemical characterization of petroleum hydrocarbon utilizers following the methods of Buchanan and Gibbons (1974).

- Total heterotrophic bacteria counts (THBC) were carried out by employing the standard plate counting technique using nutrient agar.

- The $\mathrm{CO}_{2}$ respiration rates were determined using the titrimetric analysis

\section{Determination of O and G Content (Spectrophotometry Method)}

Moist samples were collected aseptically from each bioreactor and air-dried for $48 \mathrm{~h}$. $5 \mathrm{~g}$ of each air-dried sample were extracted by vigorous hand shaking for 3 min with $20 \mathrm{~mL}$ of toluene in a separation funnel. The mixtures were allowed to settle and the extracts were decanted into a volumetric flask and plug. The above procedure was repeated two times using $20 \mathrm{~mL}$ of toluene each time (Vu-Duc et al., 2002). The total extracts were combined and diluted in the ratio 1:3 (extract: toluene), and then the absorbance of each sample was quantified using a CE 1020 (1000 Series) UV Spectrophotometer at $400 \mathrm{~nm}$. Oil and Grease contents were extrapolated from a standard curve of absorbance (A400 nm) against concentration. Values of concentration obtained were multiplied by the dilution factor (DF) to give the actual concentration.

Organic Carbon in Soil Samples (Colorimetric Method)

An amount of $0.5 \mathrm{~g}$ of contaminated soil sample sieved through $2 \mathrm{~mm}$ sieve was weighed into a glass beaker, $10 \mathrm{~mL}$ of $1 \mathrm{~N} \mathrm{~K}_{2} \mathrm{Cr}_{2} \mathrm{O}_{7}$ was added to the glass. As well, $10 \mathrm{~mL}$ of concentrated $\mathrm{H}_{2} \mathrm{SO}_{4}$ was carefully added. The solution was shaken gently and allowed to cool at room temperature. The solution was washed into $100 \mathrm{~mL}$ volumetric flask and made to the mark with distilled water. In addition, a blank solution was prepared by adding $10 \mathrm{~mL}$ of $1 \mathrm{~N} \mathrm{~K}_{2} \mathrm{Cr}_{2} \mathrm{O}_{7}$ and $10 \mathrm{~mL}$ of concentrated $\mathrm{H}_{2} \mathrm{SO}_{4}$. 0, 2, 4, 6, 8 and $10 \mathrm{~mL}$ of $2000 \mathrm{ppm}$ sucrose solutions were pipette into different flasks, 10 $\mathrm{mL}$ of $1 \mathrm{~N} \mathrm{~K}_{2} \mathrm{Cr}_{2} \mathrm{O}_{7}$ and $10 \mathrm{~mL}$ of concentrated $\mathrm{H}_{2} \mathrm{SO}_{4}$ were added to each flask. Both the blank and standard solutions were washed into $100 \mathrm{~mL}$ flask and made to mark with distilled water. The standards now contain 40, 80, 120, 160, 200 ppm. The blank, standards and samples were read on a spectrophotometer at $600 \mathrm{~nm}$. Samples concentrations were calculated using the following relation.

$\operatorname{Organic~carbon}(\mathrm{ppm})=\left(\frac{\text { average value of } \mathrm{s} \tan \text { dard }}{\text { average value of absorbance }}\right)$

$\times($ absorbance of sample $) \times D F$

\section{RESULTS AND DISCUSSION}

Physicochemical and microbiological characteristics of contaminated soil

The physicochemical and microbiological characteristics of the contaminated soil were 
Table 1: Physicochemical and microbiological characteristics of SCSMO

\begin{tabular}{lc}
\hline Parameter & Characteristic/Value \\
\hline Soil texture & Loamy Sand \\
Particle density $\left(\mathrm{g} / \mathrm{cm}^{3}\right.$ & $2.04 \pm 0.01$ \\
Bulk density $\left(\mathrm{g} / \mathrm{cm}^{3}\right)$ & $1.49 \pm 0.01$ \\
Soil porosity $(\%)$ & $26.89 \pm 0.85$ \\
pH & $7.43 \pm 0.01$ \\
O\&G $(\mathrm{g} / \mathrm{kg}) * 10^{2}$ & $1.41 \pm 0.00$ \\
WC $(\%)$ & $2.09 \pm 0.11$ \\
WAC $(\%)$ & $34.13 \pm 0.02$ \\
OC $(\mathrm{g} / \mathrm{kg}) * 10^{1}$ & $6.42 \pm 0.00$ \\
$\mathrm{~N}(\mathrm{mg} / \mathrm{kg}) * 10^{3}$ & $1.40 \pm 0.00$ \\
P $(\mathrm{mg} / \mathrm{kg})$ & $17.96 \pm 3.69$ \\
THBC $(\mathrm{CFU} / \mathrm{g}) * 10^{8}$ & $2.60 \pm 0.52$ \\
\hline D
\end{tabular}

Data presented are averages of triplicate determinations

SCSMO: soil contaminated with spent motor oil

determined and presented in Table 1 . The high level of carbon content was due to the presence of spent motor oil in the soil, which is related to the oil and grease content. The value of the oil and grease content exceeds the safe limit of $500 \mathrm{mg} / \mathrm{kg}$ set by the Nigeria Ministry of the Environment and therefore, needs intervention for public safety and environmental health. The soil texture and $\mathrm{pH}$ value obtained were adequate for effective bioremediation (Vidali, 2001). In addition, results obtained for the microbiological analyses revealed that the THBC was above the minimum value of $10^{5}$ required for effective bioremediation (Forsyth et al., 1995). Hence, the numbers of indigenous bacteria in the test soil were adequate for effective bioremediation.

\section{Environmental factors for treatments}

Table 2 presents temperature, $\mathrm{pH}$ and moisture content ranges for the three treatments over the 70 days of investigation. Results showed that the temperature and $\mathrm{pH}$ were within the $10-40{ }^{\circ} \mathrm{C}$ (Irvine and Frost, 2003) and 5.5-8.5 (Chambers, et al., 1991 and Less and Senior, 1995) required for effective bioremediation except for slight variation in $\mathrm{pH}$ over certain sampling episodes. Therefore, temperature and $\mathrm{pH}$ were not limiting factors in this study.
On the other hand, the moisture contents for the three treatments deviated significantly from the optimum range of $10-20 \%$ (w/w), (Less and Senior, 1995); the low moisture contents observed can be attributed to the presence of oil in the soil, which resulted in the blockage of the pores, hence low water retention.

Oil and grease content ( $O$ and $G$ ) removal efficiencies

The removal efficiencies of O\&G for the three treatments is presented in Table 2. From this table it can be seen that the biostimulation option (TR6) had the highest removal efficiency (75\%) over the period of study. The bioaugmentation (TR3) showed $66 \%$ removal of the $\mathrm{O}$ andG content and the control (TR1) had the least of $50 \%$. These removal efficiencies fell within the range of 30-75 \% reported by Chaineau et al (2002) for biodegradation of lubricating oil. The significant $\mathrm{O}$ and $\mathrm{G}$ removal observed for TR1 could be attributed to inadequate penetration of heat during the sterilization process as attested by the initial concentration of bacteria for TR1(Fig. 2) and the continuous supply of oxygen and water via the humidifying unit.

\section{Total heterotrophic bacteria count}

Results of total heterotrophic bacterial counts showed that the bacterial profiles obtained (Fig. 2) followed a typical growth pattern of microorganisms. It was also observed that TRI (control) had the least microbial population while TR3 and TR6 are competing in microbial populations. These observations correspond with the trend acquired for the O\&G removal efficiencies obtained. Consequently, it is evident that the microbes utilize the carbon contained in spent motor oil for growth. In addition, bacteria species identified in the test soil were Bacillus subtilis and Micrococcus leteus. The identification of these species was in line with previous investigation on spent motor oil contaminated soil (Amund et al., 1987) and in accordance with classification of Adams and Jackson (1996).

Table 2: Environmental Parameters and Oil and Grease Content ( $\mathrm{O}$ and $\mathrm{G}$ ) Removal Efficiencies for the Three Treatment Options

\begin{tabular}{|c|c|c|c|c|c|c|}
\hline \multirow{2}{*}{ Treatment and Composition } & \multicolumn{3}{|c|}{ Environmental Parameters } & \multicolumn{3}{|c|}{$\mathrm{O}$ and $\mathrm{G}(\mathrm{g} / \mathrm{kg})$ efficiency } \\
\hline & temp. $\left({ }^{\circ} \mathrm{C}\right)$ & MC (\%) & $\mathrm{pH}$ & day zero & after 70 days & (\%) \\
\hline TR1: SCSMO + HS + $\mathrm{H}_{2} 0$ & $27.00 \pm 0.5-30.60 \pm 0.4$ & $0 \pm 0.0-22 \pm 0.1$ & $6.03 \pm 0.1-7.70 \pm 0.05$ & $29.01 \pm 0.30$ & $14.44 \pm 0.22$ & 50 \\
\hline $\begin{array}{l}\text { TR3: SCSMO + HS }+\mathrm{H}_{2} 0 \\
+\mathrm{EB}\end{array}$ & $27.00 \pm 0.3-30.50 \pm 0.4$ & $1 \pm 0.1-20 \pm 0.0$ & $5.25 \pm 0.1-7.71 \pm 0.1$ & $35.52 \pm 0.35$ & $12.08 \pm 0.20$ & 66 \\
\hline $\begin{array}{l}\text { TR6: SCSMO + HS + } \mathrm{H}_{2} 0 \\
+ \text { NPK }(20: 20: 20)+\mathrm{KH}_{2} \mathrm{PO}_{4}\end{array}$ & $26.60 \pm 0.2-31.00 \pm 0.0$ & $5.2 \pm 0.1-20 \pm 0.2$ & $5.50 \pm 0.05-8.85 \pm 0.03$ & $38.59 \pm 0.24$ & $9.83 \pm 0.15$ & 75 \\
\hline
\end{tabular}




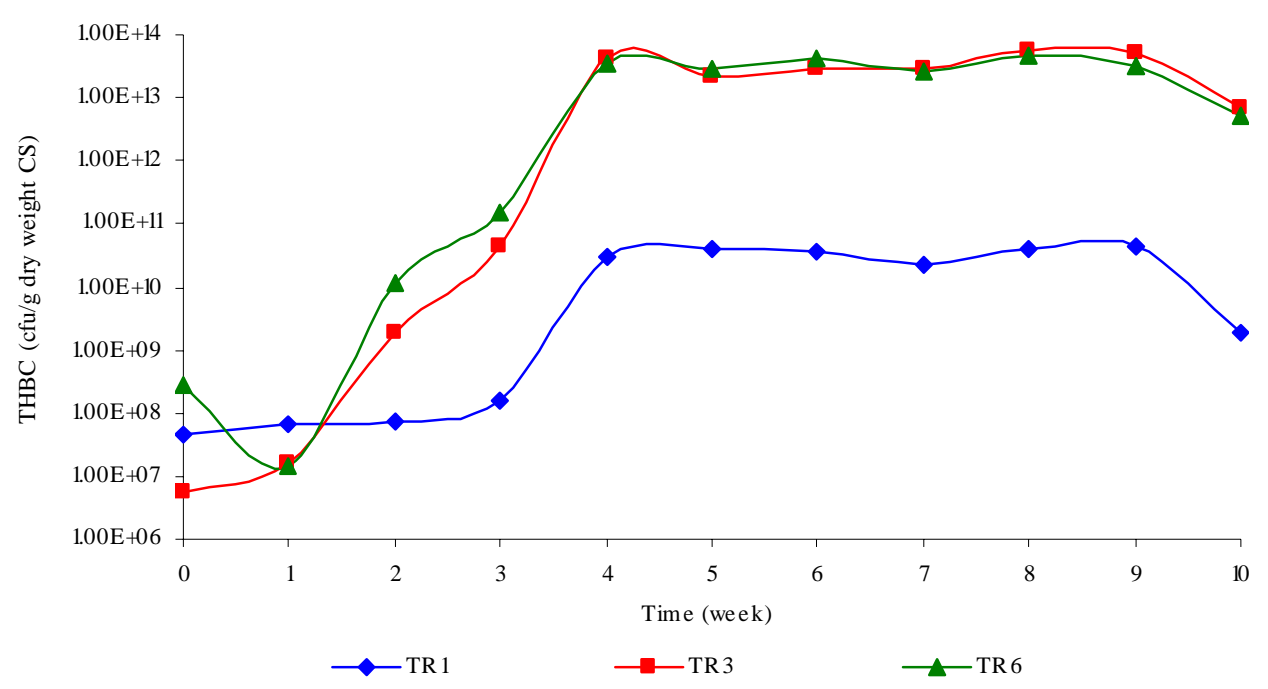

Fig. 2: Total heterotrophic bacteria counts in the three microcosms over the 70 days of investigation

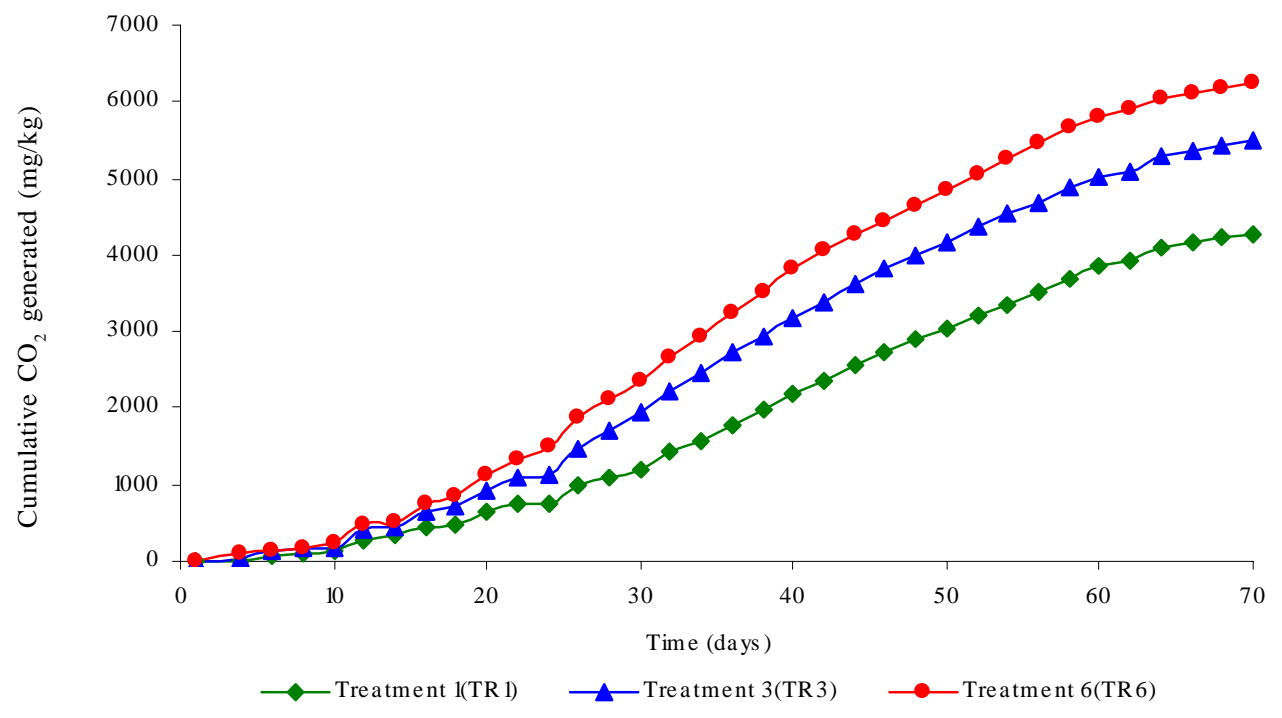

Fig. 3: Rate of Cumulative $\mathrm{CO}_{2}$ Generation over a Period of 70 days

$\mathrm{CO}_{2}$ generated from the bioremediation processes

The 48 hourly $\mathrm{CO}_{2}$ generations allowed estimation of the cumulative $\mathrm{CO}_{2}$ generations. The cumulative amount of $\mathrm{CO}_{2}$ generated for each of the three treatments is presented in Fig. 3. Result showed that just as in the case of the O\&G content, the biostimulation option (TR6) gave the best result (6249 $\mathrm{mg} / \mathrm{kg}$ ), followed by the bioaugumentation option
(TR3) with $5493 \mathrm{mg} / \mathrm{kg}$ and the control with the least of $4276 \mathrm{mg} / \mathrm{kg}$. The profiles obtained for the three treatments have similar features, which suggest that indigenous and added bacteria could be of the same genus (Bacillus subtilis).

In addition, these profiles can be divided into three periods as follows; (i) adaptation period, which is the period microorganisms used to adjust to their new 
environment or period where they synthesized the necessary enzymes for growth. In this period, there is little or no increased in the number of cells (this period lasted for the first 10 days of treatment); (ii) maximum oil degradation period (between 20-60 days) and (iii) decaying period (past 60 days). In the decaying period, the number of living microorganisms for each treatment reduced and rate of degradation slowed down. This could be likely linked to exhaustion in available nutrient in each treatment or the production of toxic metabolites.

\section{CONCLUSIONS}

From the results obtained in this research work, the following conclusions can be drawn: The petroleum removal efficiency for the spent motor can reach $75 \%$ within 70 days of bioremediation in a closed system within the range of experimental conditions used in this study, based on the $\mathrm{O}$ and $\mathrm{G}$ removal efficiency and $\mathrm{CO}_{2}$ generation, the biostimulation approach (TR6) gave the best result in this study and TR6 can be used to develop a safe and economical full-scale treatment technology for soils contaminated with spent motor oil.

\section{ACKNOLEDGEMENT}

We wish to acknowledge the academic staff union of Nigerian Universities and Abubakar Tafawa Balewa University for their financial supports for the execution of this study.

\section{REFERENCES}

Abdulsalam, S.; Omale, A. B., (2009). Comparison of biostimulation and bioaugmentation techniques for the remediation of used motor oil contaminated soil. Braz. Arch. Biol. Tech. 52 (3), 747-754 (8pages).

Adams, P.; Jackson, P. P., (1996). Bioremediation of oil spills: Theory and practice. International Bioremediation Services Limited, Westgate, Aldridge, West Midlands, 1-17 (17 pages).

Adams, R. H.; Guzmán-Osorio, F. J., (2008). Evaluation of land farming and chemico-biological stabilization for treatment of heavily contaminated sediments in a tropical environment. Int. J. Environ. Sci. Tech., 5 (2), 169-178 (10 pages)

Adams, R. H.; Olán-Castro, D.; Guzmán-Osorio, F. J.; DíazRamirez, I. J., (2009). Relationship between geomorphology and contamination with weathered hydrocarbons in an old river levee/marsh association. Int. J. Environ. Sci. Tech., 6 (4), 527-538 (12 pages).

Amund, O. O.; Adewale, A. A.; Ugogi, E. O., (1987). Occurrence and characteristics of hydrocarbon-utilizing bacteria in Nigerian soils contaminated with spent motor oil. Indian J. Microbiol. 27 (1), 63-67 (5 pages).

Anoliefo, G. O.; Edegbai, B. O., (2000). Effect of spent engine oil as a oil contaminant on the growth of two eggplant species; Solanum melongena L. and S. incanum. J. Agric. Forestry Fisheries. 1 (1), 21-25 (5 pages).

ASTM (1982a). Standard test method for laboratory determination of water content of soil, rock and soilaggregate mixtures. American Society for Testing and Materials: D 2216.

ASTM (1982b). Standard test method for laboratory determination of particle size analysis of soil, rock and soil-aggregate mixtures. American Society for Testing and Materials: D 422-63.

Bagherzadeh-Namazi, A.; Shojaosadati, S. A.; HashemiNajafabadi, S., (2008). Biodegradation of used engine oil using mixed and isolated cultures. Int. J. Environ. Res., 2 (4), 431-440 (10 pages).

Bailey, J. E.; Ollis, D. F., (1977). Biochemical Engineering Fundamentals. International Student edition, McGraw-Hill Kogakusha, Ltd, Tokyo. 335-356 (22 pages).

Bates, R. A., (1954). Electrometric determination .John Wiley and Sons, Inc. New York.

Brady, N. C.; Weil, R. R., (1999). The nature and properties of soil., 12 $2^{\text {th }}$ Edition, Prentice-Hall Inc, U.S.A, 145 p.

Buchanan, R. E.; Gibbons, N. E., (1974). Bergey’s manual of determinative bacteriology. $8^{\text {th }}$ Edition. R. E. Buchanan and Gibbons, N. E. The Williams and Wilkins Company, Baltimore.

Chaineau, C. H.; Setier, J. C.; Morillon, A., (2002). Is bioremediation s solution for the treatment of oily waste. SPE 78548, Soc. Petrol Eng. Inc. 1-10 (10pages).

Chambers, D. C.; Willis, J.; Giti-Pour, S.; Zieleniewiski, L.J.; Rickabaugh, J.F.; Mecca, M. I.; Pasin, B.; Sims, C. R.; Sorensen, L. D.; Sims, L. J.; Mclean, E. J.; Mahmood, R.; Dupont, R. R.; Wagner, K., (1991). In-situ treatment of hazardous waste contaminated soil., 2nd Edition, Noyes Data Corporation New Jersey, U.S.A, 7, 44-64 and 176209 and 299-327.

Chukwuma, M. C.; Eshett, E. T.; Onweremadu, E. U.; Okon, M. A., (2010). Zinc availability in relation to selected soil properties in a crude oil polluted eutric tropofluvent. Int. J. Environ. Sci. Tech., 7 (2), 261-270 (10 pages).

Dhanasekaran, D.; Thajuddin N.; Rashmi, M.; Deepika, T. L.; Gunasekaran M., (2009). Screening of biofouling activity in marine bacterial isolate from ship hull. Int. J. Environ. Sci. Tech., 6 (2), 197-202 (6 pages).

Forsyth, J. V.; Tsao, Y. H.; Bleam, R. D., (1995). Bioremediation: When is bioaugmentation needed?, 1-14. in R. E. Hinchee, J. Fredrickson and B. C. Alleman (Ed.) Bioremediation for site remediation. Battelle Press, Columbus, Ohio, USA.

Fouépé, T. A.; Kengni, T. L.; Gurunadha Rao, V. V. S.; Ndam, N. J. R., (2009). Transfer of moisture through the unsaturated zone in the tropical forest using the neutron probe. Int. J. Environ. Sci. Tech., 6 (3), 379-388 (10 pages).

Igwe, J. C.; Abia, A. A.; Ibeh, C. A., (2008). Adsorption kinetics and intraparticulate diffusivities of $\mathrm{Hg}$, As and $\mathrm{Pb}$ ions on unmodified and thiolated coconut fiber. Int. J. Environ. Sci. Tech., 5 (1), 83-92 (10 pages).

Irvine, D. A.; Frost, H. L., (2003). Bioremediation of soils contaminated with industrial wastes: a report on the state -of-the-art in bioremediation. SBR Technology Inc. 
Kiyohara, H.; Takizawa, N.; Nagao, K., (1992). Natural distribution of bacteria metabolizing many kinds of polyaromatic hydrocarbons. J. Ferment. Bioeng. 74 (1), 49-51 (3 pages).

Kosteck, P. T.; Calabrese, E. J., (1991). Bioremediation of Hydrocarbon Contaminated Soils: The Microbial Ecology Approach. In Hydrocarbon contaminated soils and Groundwater, Lewis Publishers, Inc. United States, 1 (1), 203-238 (36 pages).

Less, Z. M.; Senior, E., (1995). Bioremediation. A Practical Solution to Land Pollution: In Clean Technology and the Environment, Chapman and Hall, New York. 121-146 (26 pages).

Malakootian, M.; Nouri, J.; Hossaini, H., (2009). Removal of heavy metals from paint industry's wastewater using Leca as an available adsorbent. Int. J. Environ. Sci. Tech., 6 (2), 183-190 (8 pages).

Nnamchi, C. I.; Obeta, J. A. N.; Ezeogu, L. I., (2006). Isolation and characterization of some polycyclic aromatic hydrocarbon degrading bacteria from Nsukka soils in Nigeria. Int. J. Environ. Sci. Tech., 3 (2), 181-190 (10 pages).

Nwuche, C. O.; Ugoji, E. O., (2008). Effects of heavy metal pollution on the soil microbial activity. Int. J. Environ. Sci. Tech., 5 (3), 409-414 (6 pages).

Nwuche, C. O.; Ugoji, E. O., (2010). Effect of co-existing stress. Int. J. Environ. Sci. Tech., 7 (4), 697-704 (8 pages).
Refaat, A. A., (2010). Different techniques for the production of biodiesel from waste vegetable oil. Int. J. Environ. Sci. Tech., 7 (1), 183-213 (31 pages).

Shah, B. A.; Shah, A. V.; Singh, R. R., (2009). Sorption isotherms and kinetics of chromium uptake from wastewater using natural sorbent material. Int. J. Environ. Sci. Tech., 6 (1), 77-90 (14 pages).

Vidali, M., (2001). Bioremediation: An overview. J. Appl. Chem., 73(7), 1163-1172 (10 pages).

Vu-Duc, T.; Huynh, C. K.; Lafontaine, M.; Bonnet, P.; Binet, S., (2002). A Spectrophotometric Method for the Determination of Organic Soluble Matter in Bitumen Fumes. Appl. Occupational Environ. Hygiene. 17 (7), 495-500 (6 pages).

Yerushalmi, L.; Rocheleau, S.; Cimpoia, R..; Sarrazin, M.; Sunahara, G.; Peisajovich, A.; Leclair, G.; Guiot, R.S. (2003). Enhanced bioremediation of petroleum hydrocarbons in contaminated soil. Bioremed. J., 7 (1), 37-51 (15 pages).

Yousefi Kebria, D.; Khodadadi, A.; Ganjidoust, H.; Badkoubi, A.; Amoozegar, M. A., (2009). Isolation and characterization of a novel native Bacillus strain capable of degrading diesel fuel. Int. J. Environ. Sci. Tech., 6 (3), 435-442 (8 pages).

Zhang, H.; Dang, Z.; Zheng, L. C.; Yi, X. Y., (2009). Remediation of soil co-contaminated with pyrene and cadmium by growing maize (Zea mays L.). Int. J. Environ. Sci. Tech., 6 (1), 69-76 (8 pages).

\section{AUTHOR (S) BIOSKETCHES}

Abdulsalam, S., M.Sc, PhD is a lecturer at the Chemical Engineering Programme, Abubakar Tafawa Balewa University, Bauchi-Nigeria. Email: asurajud@yahoo.com

Bugaje, I. M., M. Eng., PhD is a lecturer at the Department of Chemical Engineering, University of Maiduguri, Borno State-Nigeria. Email: idrismbugage@yahoo.com

Adefila, S. S., M.Sc, PhD is a lecturer at the Department of Chemical Engineering, Ahmadu Bello University Zaria-Nigeria. Email: ssadefila@yahoo.com

Ibrahim, S., M.Sc, PhD is a lecturer at the Department of Biochemistry and Director Centre for Biotechnology, Ahmadu Bello University Zaria-Nigeria. Email: sanibro2000@yahoo.com

How to cite this article: (Harvard style)

Abdulsalam, S.; Bugaje, I. M.; Adefila, S. S.; Ibrahim, S., (2011). Comparison of biostimulation and bioaugmentation for remediation of soil contaminated with spent motor oil. Int. J. Environ. Sci. Tech., 8 (1), 187-194. 